ELORE (ISSN 1456-3010), vol. $18-1 / 2011$.

Julkaisija: Suomen Kansantietouden Tutkijain Seura ry.

[http://www.elore.fi/arkisto/1_11/kirjat_savolainen.pdf]

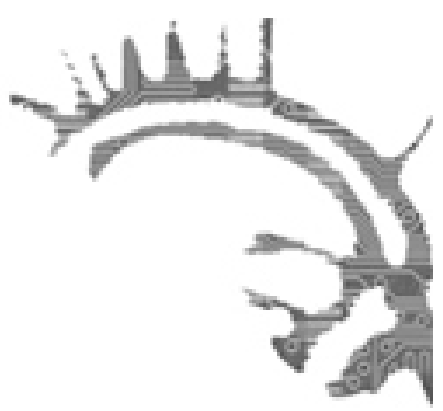

KIRJA-ARVIO

\title{
SIIRTOKARJALAISTEN SOPEUTUMISEN MONET JATKUMOT
}

KANANEN, HELI KAARINA 2010: Kontrolloitu sopeutuminen. Ortodoksinen siirtoväki sotien jälkeisessä Ylä-Savossa (1946-1959). Jyväskylä Studies in Humanities 144. Jyväskylä: Jyväskylän yliopisto. 318 sivua.

\section{Ulla Savolainen}

Heli Kaarina Kanasen Suomen historian alan väitöskirja Kontrolloitu sopeutuminen. Ortodoksinen sïrtoväki sotien jälkeisessä Ylä-Savossa (1946-1959) tarkastelee ortodoksisen karjalaisen siirtoväen sopeutumista uuteen elinympäristöön. Ortodoksisen ja luterilaisen siirtoväen vastaanotto ja sopeutuminen luterilaisenemmistöisillä paikkakunnilla oli erilaista johtuen muun muassa uskonnosta, erilaisista arvoista, normeista, tavoista ja kielestä. Kananen kysyy, mitä keinoja siirtoväki käytti sopeutuakseen ja saavuttaakseen hyväksytyn aseman uudella kotiseudulla tarkastelemalla sekä ulkoista että identiteetin tason sopeutumista. Tämän lisäksi hän tarkastelee sitä, miten viranomaistaho ja luterilainen paikallisväestö ja näiden kontrolloivat käytänteet sopeuttivat siirtoväkeä. Kananen tutkii väitöskirjassaan sopeutumista yksilön ja pienyhteisön näkökulmasta peilaten sitä myös kollektiiviseen ulottuvuuteen. Hän on kiinnostunut siitä, millaisten identiteettielementtien kautta karjalaisten ja savolaisten tai ortodoksien ja luterilaisten välillä tuotettiin yhteenkuuluvuuden tunnetta.

Kananen pyrkii tutkimuksellaan monipuolistamaan 1990-luvulle asti hallinnutta näkökulmaa siirtokarjalaisten asuttamisesta kansallisena menestystarinana. Tutkimus nostaa esiin ristiriidan niin sanotun virallisen byvän sopeutumisen bistoriantulkinnan ja kokemustiedon välillä, joka tuo esiin myös kohtaamisen ja sopeutumisen ongelmia. Kanasen mukaan väitöskirja eroaa varhaisemmasta sopeutumistutkimuksesta myös monilähteisyytensä ja -äänisyytensä vuoksi. Myöskään ortodoksien sopeutumista ei ole varhemmissa tutkimuksissa tarkasteltu yhtä kattavasti. Tutkimus rakentuu lähtökohtia ja metodeja käsittelevästä johdantoluvusta, kolmesta analyysi- tai teemaluvusta sekä yhteenvetoluvusta. 
Ulla Savolainen: Siirtokarjalaisten sopeutumisen monet jatkumot

\section{KERROKSELLISET TARKASTELUNÄKÖKULMAT, AINEISTOT JA TUTKIMUSMENETELMÄT}

Tutkimuksen keskeiset käsitteet kietoutuvat sopeutumisen, sosiaalisen kontrollin, yhteisyyden ja identiteetin ympärille. Tutkimus yhdistää eri alueellisten yhteisötasojen tarkastelun - siirtokarjalaisten sopeutumista ja sopeuttamista tarkastellaan paikallisena, maakunnallisena sekä valtakunnallisena prosessina. Tutkimuksen paikallistaso on Kiuruvesi, maakuntataso on Ylä-Savo ja valtakunnallinen taso on koko Suomi. Analyysin suunta on ruohonjuuritasolta kohti yleisempää. Kananen hyödyntää myös monenlaisia aineistoja. Muistitieto- ja haastatteluaineistot mahdollistavat ruohonjuurinäkökulman siirtoväen ja paikallisten sopeutumisen kokemuksiin ja muistoihin. Haastatteluaineistojen rinnalla Kananen käyttää eri paikallistasoihin paikantuvia virallisia asiakirja-aineistoja, kuten Kiuruveden kunnan ja käräjäoikeuden sekä Kuopion lääninhallituksen dokumentteja. Ortodoksisen siirtoväen asemaa Kananen analysoi ortodoksisen kirkon ja erityisesti Kiuruveden ortodoksisen papiston asiakirjojen ja tilastojen kautta. Näkökulma sopeutumiseen syventyy myös painetun aikalaisaineiston, kuten ortodoksisen opetuskirjallisuuden ja sanomalehtikirjoitusten diskurssianalyysillä ja vertailulla muihin aineistoihin. Kanasen menetelmänä on testata paikallistason tulkintoja maakuntatason aineiston avulla ja laajentaa tulkintoja myös kansalliseen identiteettiin ja mentaliteetteihin. Erilaisten aineistojen yhdistelyn ja vertailun pohjalta hän pyrkii konstruoimaan yhtenäisen kuvan menneestä.

Kanasen tutkimus paikantuu moniaalle historiantutkimuksen kenttään. Tutkimuksen lähtökohta on mikrohistoriallinen, sillä kysymyksenasettelut ja tutkimusaihe muotoutuivat muistitiedosta esiin nousseita johtolankoja kuten ryssäksi herjaamisen muistoja seuraamalla. Tutkimus keskittyy mikrohistorialle tyypillisesti tiettyyn lyhyen keston poikkeukselliseen tapahtumaan. Väitöskirja lähenee myös mentaliteettihistoriaa, koska mikrohistoriallista näkymää tarkastellaan suhteessa paikallisväestössä ja laajemmin yhteiskunnassa vallinneisiin siirtoväen sopeutumiseen ja vastaanottoon vaikuttaneisiin henkisiin rakenteisiin. Muita historioita, joihin Kananen työnsä paikantaa ovat identiteettibistoria, metabistoria sekä kirkkohistoria. Historiantutkimussuuntausten lisäksi Kananen hyödyntää tutkimuksessaan psykologista ja sosiologista kontrolliteoriaa, sosiaalipsykologian ja kriisipsykologian näkökulmia sekä muistitietoa.

\section{MUistitieto JA HAASTATTELUT HistoriantUTKIMUKSEN LÄHTEINÄ}

Muistitiedolla on Kanasen tutkimuksessa ensisijaisesti lähteen asema. Kananen toteaa, että erilaisten lähteiden käyttö on ollut välttämätöntä, sillä usein asiakirja-aineistot vaikenevat esimerkiksi vastakkainasettelusta ja konflikteista paikallisten ja siirtoväen välillä. Historioitsijan näkökulmasta johtuen tutkimuksessa pohdiskellaan runsaasti muistitiedon ja muistin luotettavuuden klassisia kysymyksiä ja niiden arvoa menneisyydestä kertovina todisteina. Muistitietotutkimuksen uusimpien keskustelujen näkökulmasta Kanasen faktuaalisuuden eli totuusarvon kysymyksiin ankkuroitunut 


\section{Ulla Savolainen: Siirtokarjalaisten sopeutumisen monet jatkumot}

näkökulma muisteluaineistoon on jossain määrin "vanhanaikaista" ja puuduttavaakin joskin perusteltua ottaen huomioon tutkimuksen paikantumisen. Kananen sanoo, että "[h]istoriantutkimuksessa on tutkimuskohteesta ja metodista riippumatta kyse lähteiden ja niiden antaman tiedon luotettavuuden tulkinnasta". Tutkimuksessa pohditaan myös ajan kulumisen vaikutusta muistitietoon, koska Kanasen käyttämä muistitietoaineisto koostuu kahdesta eri aikoina tuotetusta aineistokorpuksesta. Vanhempi kokonaisuus on Heikki Wariksen tutkimusryhmän1940-luvun lopulla tuottama aineisto, johon pohjautuu myös yksi suomalaisen sopeutumistutkimuksen pioneeritutkimuksista (Waris ym. 1952). Toinen aineistokorpus muodostuu Kanasen 2000-luvun alkuvuosina suorittamista haastatteluista.

\section{EPÄVIRALLISEN JA VIRALLISEN KONTROLLIN MUOTOJA}

Kananen analysoi väitöskirjassaan erilaisia epävirallisen ja virallisen kontrollin keinoja erittelemällä muun muassa Kiuruveden tilannetta sotien jälkeen, asutuksen kulkua ja sen järjestymistä sekä karjalaisiin ja etenkin ortodokseihin liittyviä aikalaiskäsityksiä. Nimittely ja pilkka, esimerkiksi ryssittely toimivat kontrollinvälineenä luterilaisen paikallisväestön määrittelemien sallitun rajojen noudattamisessa. Pilkan ja väheksynnän kautta paikallisia normeja ja arvoja välitettiin siirtoväelle ja kontrollin kautta enemmistö yritti säilyttää vallitsevan elämänmuodon ja sosiaalisen rakennelman sekä hallita muutosta. Yksi epävirallisista sopeuttamiskeinoista perustui vastakkainasettelulle stereotyyppisen luterilaisen omakuvan sekä hävettävää toiseutta edustavan siirtoväen ja erityisesti ortodoksisuuden välillä. Sosiaalisen statuksen määrittymisessä keskeisenä tekijänä oli kuuluminen siirtoväkeen tai paikallisväestöön ja myös muu kuin vain ortodoksinen siirtoväki edusti toiseutta.

Kananen paneutuu tutkimuksessaan myös siirtoväkeen kohdistuneisiin epäluuloihin ja niiden pohjalta syntyneisiin stigmoihin, jotka ainakin osittain saivat pontta maanluovutukseen ja sen omistusoikeuksiin liittyvistä kysymyksistä. Yhteiskunnallisen ja taloudellisen stigman lisäksi ortodoksiseen siirtoväkeen kohdistui myös kieli- tai etnisyysstigma, kehostigma sekä moraalinen stigma, joka viittasi niin uskonnollisiin, taloudellisiin kuin hygieenisiinkin käytänteisiin. Kanasen mukaan nämä erilaiset epävirallisen tason kontrollikäytänteet käyvät ilmi haastatteluaineiston mutta eivät asiakirja-aineiston pohjalta. Epävirallisuudestaan huolimatta ne ilmentävät siirtoväen saapumisen aiheuttamaa kulttuurista ja sosiaalista kriisiä paikallisyhteisössä, mikä perusteleekin muistitietoaineiston hyödyllisyyttä myös historiantutkimuksen lähteenä. Virallisen tason kontrollikeinot olivat usein pikemminkin rakenteellisia kuin avoimia. Ne liittyivät muun muassa tiedonvälityksen käytänteisiin, rakentamissäädöksiin, uskonnon opetuksen säätelyyn ja ylipäänsä yhtenäistävään koulujärjestelmään. Epävirallisen ja virallisen kontrollin väliin sijoittui myös sopeuttamiseen tähtääviä kirjoittamattomia käytänteitä, joita liittyi esimerkiksi eri uskontokuntiin kuuluvien vainajien hautaamiseen. 


\section{ORTODOKSISUUS, KARJALAISUUS JA YHTEISYYDEN KOKEMUS}

Siirtoväen sopeutumista ja sosiaalista statusta edistivät toiseutta korostavien, häpeällisenä pidettyjen tapojen, käytänteiden ja kulttuuripiirteiden pelkistäminen sekä niistä luopuminen. Esimerkiksi ortodoksista pyhäkkörakentamista pelkistettiin vastaamaan luterilaista normia ja perinteisten ortodoksisymboleiden tilalle tuotiin uusia korostamaan karjalaisuuden yhteyttä suomalaisuuteen ortodoksisuuden sijaan. Paikallisyhteisöä yritettiin myös sopeuttaa siirtoväen tapoihin. Esimerkiksi ortodoksinen papisto pyrki tekemään ortodoksista uskonnonharjoittamista hyväksyttäväksi ja Iisalmen Sanomat pyrki nostamaan ja oikeuttamaan siirtoväen asemaa, purkamaan ryhmästereotypioita sekä edistämään koko paikallisyhteisön yhteisyyden tunnetta.

Ortodoksinen ja raja-karjalainen siirtoväki paransi sosiaalista asemaansa myös suomalaisten hyväksymien karjalaisuuden piirteiden vahvistamisella. Karjalaisuus yhdistettiin kalevalaiseksi miellettyihin kulttuurinpiirteisiin, jotka valtaväestö koki osaksi suomalaisuutta ja positiivista karjalaisuutta. Myös muun muassa lehdistön esiintuoma siirtoväen uudisraivaajahenki, ahkeruus ja sijaiskärsijyys edistivät sïrtoväen hyväksyntää sekä oikeuttivat maanluovutuksia ja korvauksia. Kananen kuitenkin huomauttaa, että siirtoväen näkökulmasta "hyvien" karjalaisuuden piirteiden korostamisessa oli kyse pikemminkin karjalaisuuden erilaisesta representoimisesta kuin todellisesta identiteettimuutoksesta. Mielenkiintoista olisi myös pohtia, minkälainen osa näillä sopeutumisen tarpeesta esiin nostetuilla karjalaisuuden piirteillä on toisen ja kolmannen polven siirtokarjalaisten identiteetissä.

Kananen näkee, että siirtoväen ja paikallisväestön yhteisten identiteettipiirteiden korostaminen ja rakentaminen olivat keskeisiä sopeuttamisprosessissa. Ryhmien toiseuden idealle perustuneiden kontrollipiirteiden ohella paikallisyhteisöissä oli tarve yhteisyyden luomiselle, eivätkä erot ja konfliktit näin ollen ole koko totuus sopeutumisesta. Välittömästi sotien jälkeen jaetut sotakokemukset ja Neuvostoliitto yhteisenä vihollisena rakensivat yhteenkuuluvuutta siirtoväen ja paikallisasukkaiden välille. Vähitellen keskeiseksi jaetuksi kokemukseksi nousi uudisraivaajuuden ympärille kietoutuva myyttinen kokonaisuus, jossa korostui ahkeruuden, työteliäisyyden ja isänmaallisuuden eetos. Kanasen mukaan prosessissa ei ole kyse yksinomaan siirtoväen vaan molempien ryhmien sopeuttamisesta sekä suomalaisen kansallisen identiteetin uusiutumis- ja rakennustyöstä.

\section{VASTAVUOROINEN JA KERROKSELLINEN SOPEUTUMISPROSESSI}

Kanasen tutkimus osoittaa, että ortodoksisen siirtoväen sopeutumisessa oli kyse useista samanaikaisista jatkumoista. Sopeutuminen oli materiaalista ja taloudellista sekä ilmeni ulkoisesti tapojen ja sisäisesti identiteetin asteilla. Sopeutumiseen vaikutti paikallistason lisäksi keskeisesti myös valtion toimet, kuten korvausmenettelyt sekä ortodoksisen kirkkokunnan vähittäinen "hyväksyminen" osaksi suomalaista yhteiskuntaa. Sopeutumista ohjailtiin myös kontrollin avulla, ja ne kuuluvatkin samaan sosiaaliseen prosessiin. Kananen nostaa esille myös sopeutumisen ja sopeuttamisen 
vastavuoroisuuden - kontrollin kohde ei ollut prosessissa täysin ohjailtavissa, eikä sopeutuminen koskenut vain siirtoväkeä. Kontrollin toiminnan edellytyksenä oli, että siirtoväki hyväksyi jollain tasolla valtaväestön asettamat normit ja mukautui niihin eli sopeutui. Osaa kontrollitoimenpiteistä, kuten esimerkiksi ortodoksien siirtämistä väestörekisteriin vastustettiin, mikä osaltaan muovasi myös suomalaista yhteiskuntaa ja ortodoksisen kirkon asemaa siinä.

Kanasen tutkimus rikastaa suomalaista siirtoväkitutkimusta tarjoamalla moninaisen, erilaiset toimijat huomioivan näkökulman siirtokarjalaisten asutukseen ja sopeutumiseen. Erilaisia aineistoja yhdistämällä Kananen onnistuu luomaan menneisyydestä moniulotteisen kuvan, joka ottaa huomioon myös siirtokarjalaisten asutukseen liittyvät konfliktit ja negatiiviset kokemukset. Huomion kiinnittäminen erityisesti ortodokseihin on tervetullutta.

\section{KiRJALlisuUS}

WARIS, HEIKKI \& JYRKILÄ, VIENO \& RAITASUO, KYLLIKKI \& SIIPI, JOUKO 1952: Sïrtoväen sopeutuminen. Tutkimus Suomen karjalaisen siirtoväen sosiaalisesta sopentumisesta. Helsinki: Otava.

Filosofian maisteri Ulla Savolainen on folkloristiikan jatko-opiskelija Helsingin yliopistossa. 